\title{
A Educação na Encruzilhada: o Pensamento Conservador da Escola Sem Partido versus o Pensamento Libertador de Paulo Freire
}

\author{
Rafael Lopes de Sousa* \\ Luiz Antonio Dias**
}

\section{Resumo}

A primeira proposta do Movimento Escola Sem Partido (MESP) foi elaborada em 2004. Uma década depois, com a eclosão de mobilizações de movimentos conservadores Brasil afora, suas pautas ganham visibilidade midiática e angariam o apoio de parlamentares e de partidos de direita. No ano de 2016, em meio aos acontecimentos que reduziram a discussão política brasileira ao maniqueísmo direita versus esquerda, bem versus mal, patriotas versus impatriotas, as propostas do MESP serviram de baluarte nas discussões do impeachment da presidente Dilma Rousseff. O objetivo deste artigo é discutir os desdobramentos desses acontecimentos para a vida educacional dos brasileiros, seja em relação à ação docente, seja em relação à formação das próximas gerações, particularmente no que diz respeito às propostas de controle das atividades docentes conforme propugnado no projeto de lei $n^{\circ} 193 / 2016$, de autoria do senador Magno Malta do Partido Liberal (PL) do Espírito Santo.

Palavras-chave: educação, Paulo Freire, pensamento conservado, Escola Sem Partido.

* É Doutor em História Social pela Unicamp (2009). Atualmente é professor permanente do Mestrado Interdisciplinar de Ciências Humanas da UNISA (SP). canoeiros2008@gmail.com http://lattes.cnpq.br/2894569135491640

** É doutor em História Social pela UNESP-Assis (2000) e tem pós-doutorado pela Universidade de Córdoba (2015). Atua como professor no Programa de Pós Graduação em História da PUCSP e também no Mestrado Interdisciplinar de Ciências Humanas da UNISA (SP). luizhistoria@yahoo.com.br http://lattes.cnpq.br/1974637581180796 


\section{Abstract}

The first proposal of the Movimento Escola Sem Partido (MESP) was drawn up in 2004. A decade later, with the outbreak of mobilizations by conservative movements throughout Brazil, its agendas gained media visibility and garnered the support of parliamentarians and right-wing parties. In 2016, amid the events that reduced the Brazilian political discussion to right versus left Manichaeism, good versus evil, patriots versus impatriots, MESP's proposals served as a bulwark in the impeachment discussions of President Dilma Rousseff. The objective of this article is to discuss the consequences of these events for the educational life of Brazilians, whether in relation to teaching action, or in relation to the training of the next generations, particularly with regard to the proposals to control teaching activities as advocated in the project. law n ${ }^{\circ} 193 / 2016$, authored by Senator Magno Malta of the Liberal Party (PL) of Espírito Santo.

Key-words: education, Paulo Freire, conservative thought, Escola Sem Partido,

\section{Resumen}

La primera propuesta del Movimento Escola Sem Partido (MESP) se elaboró en 2004. Una década después, con el estallido de movilizaciones de movimientos conservadores en todo Brasil, sus agendas cobraron visibilidad mediática y contaron con el apoyo de parlamentarios y partidos de derecha. En 2016, en medio de eventos que redujeron la discusión política brasileña a maniqueísmo de derecha versus izquierda, bien versus mal, patriotas versus impatriotas, las propuestas del MESP sirvieron como baluarte en las discusiones de juicio político de la presidenta Dilma Rousseff. El objetivo de este artículo es discutir las consecuencias de estos hechos para la vida educativa de los brasileños, ya sea en relación a la acción docente, o en relación a la formación de las próximas generaciones, particularmente en lo que se refiere a las propuestas de control de la actividad docente preconizadas. en el proyecto de ley n ${ }^{\circ}$ 193/2016, del Senador Magno Malta del Partido Liberal (PL) de Espírito Santo.

Palabras clave: educación, Paulo Freire, pensamiento conservador, Escola Sem Partido, 


\section{Introdução}

A América Latina tem uma longa tradição de interrupção autoritária dos governos populares. Essa prática atravessou todo o século XX e, no contexto da Guerra Fria, com o apoio logístico e material dos EUA, a presença dos militares nos governos torna-se predominante em praticamente todos os países. Sem perder o traço autoritário, no inicio do século XXI, as interferências praticadas nos governos legitimamente eleitos na América Latina ganham novos contornos com a participação de influentes setores da sociedade civil que viabilizam uma formação híbrida de ingerência na vida política dos governos da região. Essa ingerência conta com a seguinte estrutura: pelo lado financeiro, é sustentada por grandes bancos e corporações empresariais; pelo lado dos costumes, recebe o apoio físico e material das igrejas evangélicas e, pelo lado constitucional, conta com o ativismo jurídico das cortes superiores que, em conluio com a imprensa, trabalham para desestabilizar e interromper os governos democraticamente eleitos na região. Assim sucedeu-se com a deposição de José Manuel Zelaya (Honduras, 2009); com a tentativa de golpe contra o governo de Rafael Correia (Equador, 2010); com a deposição de Fernando Lugo do governo (Paraguai, 2019) e com o golpe contra o governo de Evo Morales (Bolívia, 2019). No Brasil a formação dessa coalizão conservadora redundou no impeachment da presidenta Dilma Rousseff.

$\mathrm{Na}$ passagem do século XX para o XXI, o Brasil experimenta um momento de rara estabilidade política e econômica, com vigor poucas vezes vista na sua história. Nesse contexto o Governo de Luiz Inácio Lula da Silva valeu-se sobejamente das condições favoráveis legadas por seus antecessores, Itamar Franco e Fernando Henrique Cardoso, com a sonhada estabilização da moeda. As condições favoráveis advindas da estabilização monetária permitiram que ao final de seu segundo mandato, em 2010, as forças políticas da nação comungassem dos valores e princípios republicanos que pareciam apontar para o fortalecimento das instituições, com amplo respeito ao Estado Democrático de Direito. Esse compromisso 
com as regras e os valores do jogo democrático permitiu que os governos petistas avançassem em reformas e conquistas sociais para a população de baixa renda.

Entre 2003 e 2015, os governos de Lula e Dilma Roussef promoveram avanços no setor da educação como, por exemplo, a criação e expansão das universidades federais com a abertura de novos campi; a criação do Prouni (Programa Universidade para Todos) que tornou mais acessível o ingresso de jovens de baixa renda na universidade; ampliou o Fies (Sistema de Financiamento Estudantil) que ofereceu mais tranqüilidade acadêmica aos estudantes com financiamento educacional; criou também o Sistema de Cotas, garantindo aos afrodescendentes uma condição mais equânime na disputa por uma vaga na universidade, fortaleceu o Ciências sem Fronteiras, e assim permitiu que estudantes e pesquisadores tivessem a oportunidade de uma experiência acadêmica em instituições de ensino superior fora do país criou, enfim, uma série de políticas educacionais que trouxe benefícios acadêmicos e científicos e garantiu novas oportunidades de ingresso e permanência das classes menos favorecidas à universidade. Apesar dos avanços granjeados nas administrações petistas, é preciso reconhecer que essas conquistas não foram construídas em bases sólidas não configuraram, portanto, A base frágil dessas mudanças possibilitou, aliás, o surgimento de uma forte e articulada reação conservadora contra o setor educacional.

Tivemos muitas conquistas nessas últimas décadas, mas, no campo da educação, não conseguimos construir uma cultura democrática, cidadã, de solidariedade, de companheirismo e de compromisso com a transformação social. Entendemos que houve um sério descuido com a formação política e isso abriu espaço para o que estamos presenciando nesses anos mais recentes: a manipulação que incute a intolerância e o ódio. Perigosamente, agora, estamos convivendo, também, com a "cultura da delação". A delação é premiada, inclusive na escola. Ignoramos a necessidade de formação para uma cultura cidadã, de uma formação como cultura de compromissos. (GADOT'TI, 2016, p. 151) 
A partir dos anos 2010, a construção de uma narrativa de corrupção generalizada com pitadas de incompetência administrativa fez recrudescer as relações entre governo e oposição emprestou as palavras de ordem para a aglutinação de amplos setores da sociedade civil, numa campanha sem tréguas contra as políticas sociais dos governos petistas. Essa narrativa de desconstrução das políticas sociais dos governos do PT avançou para outras áreas da administração federal e criou as condições favoráveis para unificar o discurso conservador segundo o qual, os governos de esquerda estariam promovendo uma educação básica e superior com forte viés ideológico de "doutrinação comunista" que subtraia as liberdades individuais ao oferecer aos alunos um currículo com conteúdo com visão basicamente de esquerda. Segundo os membros do Movimento Escola Sem Partido, esse currículo maculava os símbolos pátrios, com a adoção de bandeiras vermelhas e a defesa de "ditaduras comunistas" "bolivarianas"; desrespeitava os preceitos e a moral da família cristã com a bandeira da educação sexual que promovia a "ideologia de gênero" ao incentivar o protagonismo feminino.

Nesse cenário corrompido e conspurcado pela ideologia de esquerda, a defesa de que o ambiente escolar seria melhor cuidado por "patriotas" e "homens de moral, tementes a Deus", ganha apoio em diversos segmentos da população e abre espaço para a ampliação de projetos de lei que visam implantar a "Escola Sem Partido".

Aprendemos com os regimes totalitários do século XX que as guerras ideológicas só conseguem lograr êxito com o controle do setor da educacional e talvez por isso, os neoconservadores do presente gritem de maneira tão estridente contra os símbolos que sustentam e orientam as bases da educação brasileira desde a redemocratização. Nessa imaginária guerra ideológica, Paulo Freire, e sua crítica ao modelo de "educação bancária", foi eleito como o inimigo primordial dessa contra-ofensiva conservadora, de sorte que toda a responsabilidade pela desordem educacional da nação é doravante imputada a ele e aos defensores de suas ideias. 
A expressão “educação bancária” nada mais é do que uma metáfora para se referir a um conjunto de práticas educacionais verticalizadas que impõe ao aluno uma "cultura do silêncio" contra a qual Freire lutou a vida inteira. Então, diferentemente do que alardeiam os representantes da MESP, Paulo Freire, nunca defendeu uma educação em que o saber seja uma prática conduzida por uma via de mão única e os alunos meros receptores do conhecimento. Ele buscou, contrariamente, fazer a critica desse modelo tradicional de educação e por isso, talvez, sua pedagogia ofereça um novo olhar, isto é, uma relação dialógica entre educador e educando como forma de superar a relação bancária que enxerga o aluno como um mero receptor passivo dos saberes. Decorre, pois, desse pensamento de Freire a sua crítica ao pensamento cristalizado de que:

a) o educador é o que educa; os educandos, os educados.

b) o educador é o que sabe; os educandos, os que não sabem.

c) o educador é o que pensa; os educandos, os pensados.

d) o educador é o que diz a palavra; os educandos, os que a escutam docilmente.

e) o educador é o que disciplina; os educandos, os disciplinados.

f) o educador é o que opta e prescreve sua opção; os educandos, os que seguem a prescrição.

g) o educador é o que atua; os educandos, os que têm a ilusão de que atuam, na atuação do educador.

h) o educador escolhe o conteúdo programático; os educando jamais são ouvidos nesta escolha se acomodam a ele.

i) o educador identifica a autoridade do saber com sua autoridade funcional, que opõe antagonicamente à liberdade dos educandos; estes devem adaptar-se às determinações daquele.

j) o educador, finalmente, é o sujeito do processo; os educandos, meros objetos (FREIRE, 1987, p. 34). 


\section{Escola sem Partido: pressupostos educacionais e ideológicos}

De autoria do Senador Magno Malta, o Projeto de Lei do Senado [PLS no 193 de 2016] $]^{1}$ ganhou rápido destaque entre muitos outros que tramitam nas Câmaras Estaduais e Assembleias Municipais. O projeto defende a introdução, com a devida normatização, da "Escola Sem Partido" em todo o território nacional. De acordo com o Ex-senador, a proposta atende aos anseios da sociedade materializados nas queixas do Movimento Escola Sem Partido (MESP). Esse movimento foi criado em 2004, pelo advogado Miguel Nagib, que na época era Procurador do Estado de São Paulo. Sua plataforma foi inspirada nas reclamações de pais e alunos que se diziam preocupados com a "doutrinação política" nas escolas em todos os níveis do ensino. Defende, entre outras diretrizes, a inspeção e fiscalização das práticas docentes e o controle do material didático enviado aos alunos, numa clara tentativa de tolher liberdade de cátedra. Quer com isso evitar qualquer possibilidade de "doutrinação ideológica”, seja nas discussões relacionadas à temática de gênero, seja nas discussões sobre sexualidade, política ou religião. Nessa cruzada pela "purificação" educacional eles reduzem os conhecimentos e experiências humanas às suas vivências individuais.

Esse movimento do Escola Sem Partido nasceu em 2004 e não gerou
muitas preocupações, porque parecia muito absurdo e coisa pequena. No
entanto, tem tomado corpo e crescido, na mesma toada de movimentos
fascistas tais como Revoltados Online, responsável por apresentar recen-
temente a proposta do Escola Sem Partido ao ministro da Educação do
governo ilegítimo. Aliás, é bom dizer que foi a primeira audiência concedi-
da pela pasta da Educação nessa gestão ilegítima. E em vídeo, os criadores
do Escola Sem Partido e do Revoltados Online explicam que criaram tais
coisas a partir de motivações pessoais. Ou seja, eles tentam impingir ao

A PLS foi retirada da votação pelo próprio autor em novembro de 2017, pois acreditava que ela teria maior chance de ser aprovada na Câmara dos Deputados primeiro e, depois, seguir para o Senado. Interessante destacar que em consulta publica aberta pelo Senado contou com 199.873 votos favoráveis e 210.819 votos contrários, o resultado indica que a disputa foi acirrada. 
país um projeto com base em impressões e vivências individuais. (MANHAS, 2016, p.19)

A proposta do Movimento Escola Sem Partido busca, pois, criar novas diretrizes que ajude a normatizar as atividades de ensino. Caso triunfe esse novo código de conduta os professores devem orientar-se prioritariamente pela:

[...] neutralidade política, ideológica e religiosa do Estado; pluralismo de ideias no ambiente acadêmico; liberdade de aprender e de ensinar; liberdade de consciência e de crença; reconhecimento da vulnerabilidade do educando como parte mais fraca na relação de aprendizado; educação e informação do estudante quanto aos direitos compreendidos em sua liberdade de consciência e de crença; direito dos pais a que seus filhos recebam a educação religiosa e moral que esteja de acordo com as suas próprias convicções. (BRASIL, 2016)

A ingerência na vida docente não se limita à presunção de indicar o que é "ato de ensinar"; a proposta vai além e estabelece em seu artigo $5^{\circ}$ diversas diretrizes para o "bom" desempenho do professor em sala de aula tais como: (i) não se aproveitará da audiência cativa dos alunos, para promover os seus próprios interesses, opiniões, concepções ou preferências ideológicas, religiosas, morais, políticas e partidárias; (ii) não favorecerá nem prejudicará ou constrangerá os alunos em razão de suas convicções políticas, ideológicas, morais ou religiosas, ou da falta delas; (iii) não fará propaganda político-partidária em sala de aula nem incitará seus alunos a participar de manifestações, atos públicos e passeatas; (iv) ao tratar de questões políticas, socioculturais e econômicas, apresentará aos alunos, de forma justa, as principais versões, teorias, opiniões e perspectivas concorrentes a respeito; (v) respeitará o direito dos pais dos alunos a que seus filhos recebam a educação religiosa e moral que esteja de acordo com as suas próprias convicções; (vi) não permitirá que os direitos assegurados nos itens anteriores sejam violados pela ação de estudantes ou terceiros, dentro da sala de aula.” (ESCOLA SEM PARTIDO, 2020). 
O cumprimento dessas normativas seria garantido com a afixação de cartazes com as orientações do comportamento a ser seguido no interior dos prédios escolares. Então, se as ideias pedagogias do MESP tivessem prosperado, o Brasil seria a primeira nação democrática do mundo com uma legislação educacional protegida por big brother.

O disciplinamento das atividades docente foi propugnado pelo Projeto de Lei no Senado (PLS), posteriormente ganhou apoio de manifestações conservadoras que tomou as ruas e as redes sociais em defesa do "Movimento Escola sem Partido". O elemento comum passa por uma rejeição ampla às causas da diversidade e dos grupos historicamente marginalizados, bem como a incorporação de suas demandas no currículo da educação brasileira. Conforme destaca Moura (2016).

[...] se algumas políticas inclusivas são até bastante aceitas, pelo menos em um primeiro momento, como a inserção de história e cultura negra e indígena nos currículos brasileiros, outras políticas ainda são imediatamente rejeitadas como é o caso da discussão de gênero. Não queremos dizer, com isso, que haja um cumprimento efetivo das leis 10.638 e 11.645, pois inúmeros são os trabalhos denunciando o não cumprimento da lei. Nem que a questão da cultura negra não desperte manifestações de intolerância religiosa e racismo, porém a questão da problematização das identidades sexuais e, principalmente, de gênero, parece mais problemáticas devido à falta de discussão e, mesmo, devido a compreensões diversas sobre os termos identidade, diferença, diversidade e multiplicidade. Outra razão que influi bastante é a campanha contrária às discussões de gênero promovida pelos grupos conservadores, incluindo leis que vedam as discussões de gênero, como vimos nos capítulos anteriores. (MOURA, 2016, 111-2)

De todas essas demandas e propostas defendidas pelo MESP, a denominada "ideologia de gênero" foi a que mais impacto causou no cotidiano das pessoas. A pauta de costumes, exaustivamente trabalhada pelas igrejas evangélicos, ganha com a militância do MESP contornos mais extensos e radicais. Segundo esse discurso reducionista os professores são useiros e vezeiros na prática de "doutrinar" 
os alunos, numa "militância" pedagógica sem tréguas, que busca "normalizar" comportamentos "inaceitáveis" (como a homossexualidade) nas dependências da escola. Essa visão distorcida da realidade criou, ainda assim, novas palavras de ordem e serviu de guia para perseguição de educadores. Nessa conjuntura de recrudescimento das opiniões e visões de mundo, todos os esforços feitos por educadores e democratas para tornar a vida mais plural, foram reduzidos ao maniqueísmo do certo e do errado desconsiderando, pois, as vontades, desejos e liberdade individual de cada sujeito.

Nos Parâmetros Curriculares para o ensino médio, a situação é talvez pior: a palavra gênero aparece uma única vez, na seção de História, em uma discussão sobre a cidadania no Brasil. Novamente, surge sem uma explicação do seu significado e podendo ser substituída por sexo, mantendo-se o sentido do texto. Entretanto, há, ao longo das recomendações, uma preocupação com a "pluralidade de sujeitos" e com as identidades individuais e coletivas, especificamente as de grupos minoritários entendendo as mulheres como um destes grupos (BRASIL, 2013). (MOURA, 2016, 116)

A popularização das novas tecnologias de comunicação e informação trouxe mudanças significativas para as relações sociais na hipermodernidade. Atualmente, temos acesso quase que instantâneo a praticamente todas as informações, descobertas e novidades científicas que antes estavam restritas a um circulo de "privilegiados". Apesar dessa nova condição, isto é, da popularização e difusão dos recursos e plataformas tecnológicas a escola permanece, ainda assim, sem fazer o uso adequado de todas as suas vantagens. Ela está como o anjo da história ${ }^{2}$, presa às lembranças e práticas do passado e, por isso mesmo, insegura em encarar o presente e todas as possibilidades que as novas ferramentas tecnológicas abrem para seus usuários no futuro. Daí o inarredável conflito de apoiar um modelo escolar que apenas reproduz conhecimento, mas não prepara o aluno para se relacionar de maneira crítica com as neces-

2 Mais informações a esse respeito ver: Walter Benjamin. As teses sobre o conceito de História. In. Obras escolhidas, Vol. 1, p. 222-232. São Paulo, Brasiliense, 1985. 
sidades de seu tempo. Tarefa nada fácil, uma vez que os desafios e mudanças ocorrem em ritmo frenético.

Vivemos, nas duas últimas décadas, uma desintegração dos valores: nin-
guém sabe mais o que é certo, bom, amigo, masculino, feminino, criança,
futuro, corpo, presente, saúde etc. Tudo é sempre provisório, as interpre-
tações multiplicam-se, como camadas. Vivemos uma mudança de meios,
uma enxurrada de informações, o mundo vive um processo de instabili-
dade e incerteza econômica, social, climática, e o modelo educacional nas
escolas públicas e privadas, fundado em verdades, em saberes acumulados,
sem espaço para a invenção e para a dúvida, não foi preparado para isso.
Os altos índices de evasão escolar, o baixo rendimento dos alunos, o de-
sinteresse e a falta de estímulo que atingem a quase todos, o aumento
da violência no espaço escolar manifesta a exaustão de estruturas muito
antigas e a necessidade de reconstrução. Sem perspectivas diante dos inú-
meros desafios do mundo atual, a escola já não satisfaz ninguém: nem
alunos, nem professores, nem gestores, nem as cidades, nem o mercado.
(2013:53-54)

As reflexões de Mosé deixam entrever que os conflitos vivenciados no chão da escola resultam da desintegração dos valores com os quais a sociedade conviveu nas últimas duas décadas. A difusão da tecnologia digital, que entrou na escola pelo bolso de seus freqüentadores, acelerou esse processo ao descortinar novos horizontes de pesquisa naquele espaço, expondo, assim, um salutar conflito entre práticas escolares consagradas e as necessidades mais urgentes de seus usuários.

Daí resultou uma escola mais plural que incorporou em seu cotidiano as novas ferramentas tecnológicas como parceiras pedagógicas; seu uso, ademais, redimensionou a formação docente e fortaleceu o aprendizado, bem como a formação cidadã dos alunos. Assim, numa sociedade com grandes disparidades socioeconômicas, a escola torna-se um espaço "privilegiado" onde o individuo encontra as condições adequadas e os meios necessários para preparar e realizar seus projetos de vida. O acesso à tecnologia ajuda, portanto, a melhorar as condições de aprendizado e torna-se elemento indispensável para a formação intelectual como cidadã do 
aluno. Se privar o aluno dessa formação mais ampla, a sociedade priva-o também da oportunidade de buscar e desenvolver projetos para o seu futuro.

A escola, cada vez mais, deverá ser um espaço aberto, e a educação, inevitavelmente vinculada à cultura. A vida deve ser a dimensão integradora das relações na escola. Se não houver vida naquilo que aprendemos, então não há educação, formação e muito menos aprendizagem. A escola deve ser um corpo vivo. E deve envolver também os espaços públicos e as festividades, deve ir a concertos, às exposições de arte, aos museus e às bibliotecas, aos centros de pesquisa, às reservas ambientais, enfim a escola deve ir à cidade. $\mathrm{E}$ a cidade deve se preparar para recebê-la, construindo espaços de convivência e de relação e assumindo seu papel no processo educativo, em vez de lavar as mãos, enquanto isola jovem e crianças em escolas que mais parecem presídios. Esperando cidadania enquanto oferecem exclusão. A escola deve ser um espaço de conexão, de ligação e inclusão. (MOSÉ, 2013:83).

Apesar do discurso de defesa permanente de sua importância, a educação nunca foi tratada como prioridade no Brasil. A agenda política nos informa, entretanto, que no próximo verão mais verbas serão destinadas aos seus usuários e mais ações serão ensejadas a fim de propagar um ensino de qualidade para todos. Mas como alcançar essa excelência de qualidade num cenário de ataques e desvalorização dos profissionais da educação como o atual? Como encontrar tranqüilidade para trabalhar quando, amparado por autoridades o MESP persegue, intimida e criminaliza as atividades dos professores? Em outras palavras, tolhe e cerceia a liberdade de cátedra e impõe um clima de insegurança para o desenvolvimento da atividade docente.

Nessa escola, nenhum professor terá segurança para ensinar, pois não saberá como sua aula será julgada - e isso se estende a qualquer área do conhecimento. Ministrar uma aula de História Geral sobre as diferentes revoluções, a luta das mulheres pelo direito ao voto ou as duas grandes guerras passará a ser arriscado. Também não será simples, nas aulas de Biologia, apresentar aos estudantes a teoria da evolução de Darwin, diante 
da emergência do fundamentalismo cristão no Brasil e sua perspectiva criacionista. (CARA, 2016, p. 45)

A partir de 2014 com o acirramento das disputas políticas no país, as criticas antes direcionadas apenas à educação básica avançam também em direção às universidades, conforme destaca Penna (2016):

As imagens do professor e da escola/universidade como o agente e o espaço da corrupção de menores inocentes vão se multiplicando nas páginas de defesa do Escola Sem Partido. [...] As universidades, controladas pelo PT, estariam praticando bullying ideológico contra os alunos universitários e transformando-os em militantes com camisas do Che Guevara. (p. 97-8)

Uma das primeiras vítimas dessa política de cerceamento e cancelamento das liberdades acadêmicas foi o professor Luís Felipe Miguel, que em 2016, ofertou a disciplina: “o Golpe de 2016 e o futuro da democracia no Brasil", na Universidade de Brasília (UnB). A iniciativa acadêmica desse professor gerou inúmeras críticas e denúncias de partidarização dentro e fora da universidade. Uma dessas reações veio da imprensa corporativa num artigo intitulado "Golpe ou impeachment, ainda", de 22/04/2018, assinado por Otávio Frias Filho, diretor editorial da Folha de S. Paulo. Nesse artigo, em aberta defesa da narrativa de "impeachment", Frias, em contraposição à tese de golpe do professor Miguel, afirma: "A liberdade de cátedra é ampla o bastante para autorizar muito disparate" sobre os cursos criados em todo o país e no exterior para discutir o Golpe de 2016; o jornal sustenta a legalidade e legitimidade do processo alegando que, "[...] antecessores praticaram pedaladas, mas as do governo Dilma foram em escala ao menos dez vezes maior [...]. Do ângulo processual, a deposição ocorreu de acordo com a lei. [...] o governo entrará em colapso [...] reflexo da perda de sustentação da sociedade [...]”. (FRIAS FILHO, 2018, p. 79).

Sabemos, desde Karl Marx, que um acontecimento histórico quando se repete é quase sempre por sua variável trágica. Assim, 
não causa espanto o fato de Frias Filho utilizar como base argumentativa para explicar o golpe de 2016, justificativas semelhantes àquelas utilizadas por este periódico para legitimar o golpe de 1964. Gadotti (2016) reflete a respeito das semelhanças entre esses acontecimentos da seguinte maneira:

Isso nos lembra 1964. A primeira vítima do golpe de 1964 foi a Educação Popular, estreitamente associada à Cultura Popular. O Programa Nacional de Alfabetização (PNA) de Paulo Freire, criado em 21 de janeiro de 1964, foi extinto dia 14 de abril de 1964, um dia antes da posse do golpista Marechal Castelo Branco, por ato de Ranieri. Mazzilli, presidente em exercício. Neste ato, ele afirma que extinguiu o PNA para "preservar as instituições e tradições de nosso País”. (GADOTTI, 2016, p. 155)

Por isso, não causa surpresa que na esteira da criminalização das atividades docentes, a competência pedagogia de Paulo Freire seja também questionada. Assim, paralelamente aos projetos de cerceamento das atividades docentes, o Movimento Escola Sem Partido, em uma estratégia de guerra, passa a incentivar seus membros a ingressarem com ações jurídicas nas diversas esferas do poder publico para questionar e se possível retirar as referências a Paulo Freire como patrono da educação brasileira.

A particular implicância do MESP contra Paulo Freire decorre das criticas que Freire faz à educação neutra e ao educador como mero reprodutor do status quo. Esse posicionamento, segundo membros do MESP, comprova as intenções distorcidas dessa pedagogia que utiliza a escola como instrumento para despertar rancores sociais, quando deveria trabalhar para ajudar a construir a "harmonização social".

Esse reducionismo da concepção pedagógica freireana obnubilou o debate em torno das variáveis de que: ensinar não se limita a transferir conhecimento, mas criar possibilidades para a sua construção. Para Freire, essas possibilidades só podem ser alcançadas em um ambiente dialógico que incentive e desperte a curiosidade dos educandos. Autonomia que o MESP repele.

Ao rejeitar a autonomia do educador, o MESP argumenta que quer retirar os elementos políticos da sala de aula garantindo, 
assim, a neutralidade do educador no ato de ensinar. Como se fosse possível dissociar os imbricados vínculos de ensino, educação e política da ação humana. O mais grave, porém, é que ao propor cerceamento da atividade docente, o MESP atenta contra a Constituição que, em seu artigo $5^{\circ}$, assegura a livre manifestação do pensamento e, na seção dedicada à educação, definida como direito de todos e dever do Estado e da família, com a colaboração da sociedade, a Carta Constitucional inclui entre os princípios do ensino a liberdade de aprender, ensinar, pesquisar e divulgar o pensamento, a arte e o saber, além do pluralismo de ideias e de concepções pedagógicas.

Por essa via a educação não pode, então, ser apenas a representação dos saberes verticalizados e acumulados pela humanidade. Ela precisa e deve necessariamente de ir além e ser o instrumento de problematização das práticas e experiências cotidianas de seus usuários. Ou, conforme explica Freire (2017):

\begin{abstract}
Por que não há lixões no coração dos bairros ricos e mesmo puramente remediados dos centros urbanos? Esta pergunta é considerada em si demagógica e reveladora da má vontade de quem a faz. É pergunta de subversivo, dizem certos defensores da democracia. Por que não discutir com os alunos a realidade concreta a que se deva associar a disciplina cujo conteúdo se ensina, a realidade agressiva em que a violência é a constante e a convivência das pessoas é muito maior com a morte do que com a vida? Por que não estabelecer uma necessária "intimidade" entre os saberes curriculares fundamentais aos alunos e a experiência social que eles têm como indivíduos? Por que não discutir as implicações políticas e ideológicas de um tal descaso dos dominantes pelas áreas pobres da cidade? Que ética de classe está embutida neste descaso? (FREIRE, 2017, p. 32).
\end{abstract}

Fazer com que o aluno perceba que o conteúdo passado em sala de aula está diretamente relacionado com sua vida social ajuda-o a compreender melhor o mundo e o torna uma pessoa mais consciente de suas responsabilidades sociais. Em outras palavras, na pedagogia freireana a leitura de mundo precede a leitura da palavra. Portanto, se o aluno consegue fazer uma leitura crítica de sua realidade, ele desenvolve idéias e soluções mais abrangentes para a 
compreensão de sua vida. Ocorre que a ideologia dominante usa todos os seus recursos para vender a idéia de que a escolarização deve permanecer neutra e transmitir apenas conteúdo sem contextualizar ou relacionar com a vida do educando. A esse respeito Freire (2017) alerta.

Creio que nunca precisou o professor progressista estar tão advertido quanto hoje em face da esperteza com que a ideologia dominante insinua a neutralidade da educação. Desse ponto de vista, que é reacionário, o espaço pedagógico, neutro por excelência, é aquele em que se treinam os alunos para práticas apolíticas, como se a maneira humana de estar no mundo fosse ou pudesse ser uma maneira neutra. [...] Enquanto presença não posso ser uma omissão, mas um sujeito de opções. Devo revelar aos alunos a minha capacidade de analisar, de comparar, de avaliar, de decidir, de optar, de romper. Minha capacidade de fazer justiça, de não falhar à verdade. Ético, por isso mesmo, tem que ser o meu testemunho (FREIRE, 2017, p.95-96).

O curioso é que, três décadas antes de toda intolerância plantada pelo MESP nas redes sociais, os Parâmetros Curriculares Nacionais elaborados pela secretaria de Educação Fundamental do Ministério da Educação, trabalhando em consonância com a pedagogia freireana, já apontava os caminhos para o professor fugir das armadilhas ideológicas da "educação neutra", comprometida apenas em transmitir conhecimentos técnicos para os alunos. Contra esse engessamento, os PCNs oferecem dez diretrizes de trabalho para o professor e o aluno. Apesar de longas, salientamos a importância de apresentar a íntegra dessas diretrizes ao leitor, uma vez que no detalhamento de cada uma de suas delas é possível encontrar uma resposta estruturada às críticas extemporâneas que o MESP faz à educação brasileira: (i) compreender a cidadania como participação social e política, assim como exercício de direitos e deveres políticos, civis e sociais, adotando, no dia-a-dia, atitudes de solidariedade, cooperação e repúdio às injustiças, respeitando o outro e exigindo para si o mesmo respeito; (ii) posicionar-se de maneira crítica, responsável e construtiva nas diferentes situações sociais, utilizando o diálogo como forma 
de mediar conflitos e de tomar decisões coletivas; (iii) conhecer características fundamentais do Brasil nas dimensões sociais, materiais e culturais como meio para construir progressivamente a noção de identidade nacional e pessoal e o sentimento de pertinência ao país; (iv) conhecer e valorizar a pluralidade do patrimônio sociocultural brasileiro, bem como aspectos socioculturais de outros povos e nações, posicionando-se contra qualquer discriminação baseada em diferenças culturais, de classe social, de crenças, de sexo, de etnia ou outras características individuais e sociais; (v) perceber-se integrante, dependente e agente transformador do ambiente, identificando seus elementos e as interações entre eles, contribuindo ativamente para a melhoria do meio ambiente; (vi) desenvolver o conhecimento ajustado de si mesmo e o sentimento de confiança em suas capacidades afetiva, física, cognitiva, ética, estética, de inter-relação pessoal e de inserção social, para agir com perseverança na busca de conhecimento e no exercício da cidadania; (vii) conhecer o próprio corpo e dele cuidar, valorizando e adotando hábitos saudáveis como um dos aspectos básicos da qualidade de vida e agindo com responsabilidade em relação à sua saúde e à saúde coletiva; (viii) utilizar as diferentes linguagens - verbais, musical, matemática, gráfica, plástica e corporal - como meio para produzir, expressar e comunicar suas ideias, interpretar e usufruir das produções culturais, em contextos públicos e privados, atendendo a diferentes intenções e situações de comunicação; (ix) saber utilizar diferentes fontes de informação e recursos tecnológicos para adquirir e construir conhecimentos; (x) questionar a realidade formulando-se problemas e tratando de resolvê-los, utilizando para isso o pensamento lógico, a criatividade, a intuição, a capacidade de análise crítica, selecionando procedimentos e verificando sua adequação. (Parâmetros Curriculares Nacionais - 02/10/2020)

\section{Considerações Finais:}

Paulo Freire foi, sem dúvida, a maior expressão da concepção libertadora de educação no Brasil do século XX. Então, contrariamente do que afirmam os seus detratores, sua obra é uma perma- 
nente condenação de um espaço escolar dogmático e doutrinador. A esse respeito ele diz:

O respeito aos educandos não pode fundar-se no escamoteamento da verdade - a da politicidade da educação e na afirmação de uma mentira: a sua neutralidade. Uma das bonitezas da prática educativa está exatamente no reconhecimento e na assunção de sua politicidade que nos leva a viver o respeito real aos educandos ao não tratar, de forma sub-reptícia ou de forma grosseira, de impor-lhes nossos pontos de vista. (FREIRE, 2007, p.40)

A pedagogia freireana é, portanto, portadora de uma dimensão política que enxerga o processo educativo como uma via de mão dupla. Essa concepção implodiu a idéia do educador como dono do saber, cuja principal tarefa é transmitir conteúdo acriticamente. Em lugar disso Freire propõe que as redes de experiências e vivências humanas sejam trabalhadas e contextualizadas de maneira critica no cotidiano da escola com os educandos; o que faz do ato de conhecer um ato político.

Esses fundamentos aproximação e divisão de responsabilidades entre educador e educando gerou desconfiança e produziu um sentimento persecutório nos membros do MESP que, sob o pretexto de criticar a visão dialógica libertadora da pedagogia de Paulo Freire, afirmam: “[...] Essa tal consciência crítica, formada desse modo, ajudará mesmo os alunos a se libertarem da sua ignorância e os estimulará a buscar e evoluir no domínio do conhecimento, ou servirá sobretudo para transformá-los em militantes da causa ideológica marxista [...]”. Na sequência deixam transparecer a visão reducionista e preconceituosa sobre os temas da educação e, assim, prosseguem: “[...] Como é que pessoas que nem sequer sabem ler e escrever entenderão no ato mesmo de serem alfabetizados, assuntos políticos, governamentais e trabalhistas altamente complexos? Não será o estudo aprofundado justamente um pré-requisito para ser capaz de formar opinião sobre esses assuntos"?

Ao denotar que o estudante não está preparado para discutir assuntos "altamente complexos", os seguidores do MESP reafir- 
mam a predileção por uma escola onde os saberes transitam por uma via de mão única cuja missão precípua é a defesa e manutenção do status quo. Não apresentam, porém, um arcabouço teórico que justifiquem essa predileção. Suas criticas baseiam-se contrariamente em generalizações vagas e imprecisas de que a escola brasileira é um espaço de "libertinagem" e "doutrinação marxista". Nessa Sodoma e Gomorra educacional o professor, segundo o MESP, é o principal responsável, pois abandonou o seu ofício de ensinar para fazer proselitismo político em sala de aula contra o sistema capitalista. Preconizam, assim, que numa escola "ideal" o educador não pode promover suas opiniões ou preferências, nem incentivar alunos a participar de manifestações que questionem as regras estabelecidas para o convívio social. Meta que seria alcançada somente com uma escola neutra.

Como vimos essa educação pretensamente neutra é denominada por Freire de bancária (1987), ou seja, uma escola sem nenhuma conexão com o contexto sociocultural e socioeconômico do aluno. Uma escola, enfim, que oculta as contradições sociais e distorcer os fatos e a realidade a fim de manter inalterada a estrutura social. A neutralidade é, pois, um elemento a mais no jogo de manipulação e busca do controle ideológico contra a emancipação dos oprimidos. Paulo Freire abriu divergência contra esse pensamento pedagógico neutro, que impõe limite às potencialidades dos educandos e apresentou outro roteiro de educação pensada Com o educando oprimido e não Para o educando o oprimido. O objetivo é que nessa nova dimensão educacional os silenciados pela história falem e, mais do que falar, enxerguem-se como atores históricos. Eis aí um dos motivos basilares que empurrou o MESP à rejeitar sectariamente o método freireano de ensino: medo de que a consciência social promova a emancipação dos oprimidos.

Assim, longe de ser panfletária e doutrinadora, a obra de Paulo Freire é um contrapondo ao conservadorismo da escola neutra que enxerga o educador como um mero transmissor de conteúdo sem autonomia para dialogar com as realidades e o cotidiano do 
educando. Se para Freire esse diálogo é a porta para a humanização do sujeito, para o MESP é o um caminho que levará a rompimentos institucionais. Daí a necessidade de controlar e vigiar as atividades do professor, a fim de que este não utilize de seus privilégios de cátedra para doutrinar jovens indefesos, cativos de suas vontades. Conforme um de seus representantes: "em sala de aula o professor não pode ter liberdade de expressão. Ali, ele é obrigado a transmitir o conteúdo." [...] "Não é prudente que se debatam assuntos que estão no noticiário dentro de sala de aula, por exemplo." (RESENDE, 2015).

Nesses tempos sombrios em que a sociedade brasileira encontra-se dividida em opiniões extremistas que nos empurra para a uma guerra fratricida, revisitar a proposta pedagógica de Paulo Freire pode nos ajudar a encontrar saídas para esse labirinto da desrazão. O dialogo entre os diferentes se faz necessário para a construção de uma sociedade mais justa, fraterna e humana. Essa sociedade ainda não está pronta, mas sua construção tem de levar em conta os preceitos de uma escola livre com um ensino plural que pense a multiplicidade de possibilidades de existência do humano.

\section{Referências}

BENJAMIN, W. As Teses sobre o Conceito de História. In: Obras Escolhidas, Vol. 1, p. 222-232. São Paulo, Brasiliense, 1985.

BRASIL. Secretaria de Educação Fundamental. Parâmetros Curriculares Nacionais. Brasília, MEC/SEF, 1997

BRASIL. Senado Brasileiro. Projeto de Lei do Senado n ${ }^{\circ}$ 193, de 2016

https: / / legis.senado.leg.br/sdleggetter / documento?dm =569947\&t$\mathrm{s}=1593930177688 \&$ disposition=inline acessado em 11 de outubro de 2020

CARA,Daniel. O Programa "Escola sem Partido" quer uma Escola sem Educação.in AÇÃO Educativa Assessoria, Pesquisa e Informação (Org.). A ideologia do movimento Escola Sem Partido: 20 autores desmontam o discurso — São Paulo: Ação Educativa, 2016. 
ESCOLA SEM PARTIDO. Disponível em: www.escolasempartido.org.br Acessado: em 30 de setembro de 2020.

ESCOLA SEM PARTIDO.org/blog/por-que-o-pensamento-pedagogico-de-paulo-freire-leva-a-doutrinacao-ideologica-politica-e-partidaria. Acesso: 30 de setembro de 2020 .

FREIRE, Paulo. Pedagogia do oprimido, $17^{\text {a }}$ Ed. Rio de Janeiro, Paz e Terra, 1987. Política e educação. 8.ed. São Paulo: Villa das Letras, 2007.

Pedagogia da Autonomia: saberes necessários à prática educativa. Rio de Janeiro: Paz e Terra, 2017.

FRIAS FILHO, Otávio. Golpe ou impeachment, ainda. In Folha de S. Paulo, p. 79, 22/04/2018.

GADOTTI, Moacir. A Escola Cidadã Frente ao "Escola Sem Partido". in AÇÃO Educativa Assessoria, Pesquisa e Informação (Org.). A ideologia do movimento Escola Sem Partido: 20 autores desmontam o discurso — São Paulo: Ação Educativa, 2016.

MANHAS, Cleomar. Nada mais Ideológico que "Escola Sem Partido".in AÇÃO Educativa Assessoria, Pesquisa e Informação (Org.). A ideologia do movimento Escola Sem Partido: 20 autores desmontam o discurso - São Paulo: Ação

MOSÉ, Viviane (org.) A escola e os desafios contemporâneos. Rio de Janeiro: Civilização Brasileira, 2013.

MOURA, Fernanda Pereira de.“ESCOLA SEM PARTIDO”: Relações entre Estado, Educação e Religião eos Impactos no Ensino de História. Dissertação de Mestrado. Universidade Federal do Rio de Janeiro. Dezembro / 2016

PENNA,Fernando.O Ódio aos Professores. in AÇÃO Educativa Assessoria, Pesquisa e Informação (Org.). A ideologia do movimento Escola Sem Partido: 20 autores desmontam o discurso — São Paulo: Ação Educativa, 2016.

RESENDE, Leandro. 'Escola sem partido' quer fim da 'doutrinação de esquerda'. In: Jornal O Dia, 06/09/2015. Disponível em: http://odia.ig.com.br/noticia/brasil/2015-09-06/escola-sem-partido-quer-fim-da-doutrinacao-de-esquerda. html. Acesso em: 05/10/2020 